\title{
The Effects of the 2010 Chilean Natural Disasters on the Stock Market
}

\author{
José Luis Ruiz \\ Facultad de Economía y Negocios \\ Universidad de Chile \\ jlruiz@fen.uchile.cl \\ Marcelo Barrero \\ Facultad de Economía y Negocios \\ Universidad de Chile \\ mbarrero@fen.uchile.cl
}

\begin{abstract}
The 2010 Chilean earthquake and tsunami were among the strongest in the world history. The exogeneity of these natural disasters provides the opportunity to test stock price reactions. Using a sample of 42 firms listed in the Santiago Stock Exchange, we develop an event study methodology considering heterogeneity in volatility. Chilean stock market volatility increased by $240 \%(120 \%)$ during the 5 (11) trading days after the earthquake. The results are informative about the behavior of the stock prices: returns are positive in sectors the retail, real estate, and banking sectors and negative in food, steel, and forestry. Insurance coverage decreases the impact on economic growth.
\end{abstract}

Keywords: Earthquake, natural disaster, stock returns, volatility.

JEL Classification: G11, G12, G14. 


\section{Resumen}

El terremoto y tsunami chileno del 2010 se encuentran entre los de mayor fuerza en la historia mundial. La exogeneidad de estos desastres naturales nos entrega la oportunidad de probar las reacciones de los precios accionarios. Usando una muestra de 42 empresas listadas en la Bolsa de Comercio de Santiago, desarrollamos el uso de la metodología de estudios de eventos considerando heterogeneidad en volatilidad. La volatilidad de la bolsa accionaria chilena aumentó en $240 \%$ (120\%) durante los 5 (11) días de transacciones posteriores al terremoto. Los resultados son informativos acerca del comportamiento de los precios accionarios: Retornos son positivos en sectores como retail, inmobiliario y bancos, mientras que fueron negativos en sectores como alimentos, acero y forestal. La cobertura de seguros disminuyó el impacto en el crecimiento económico.

Palabaras clave: Terremoto, desastre natural, retornos accionarios, volatilidad.

\section{Introduction}

Two catastrophic events, an earthquake and tsunami, affected Chile on February 27, 2010. The earthquake was felt in six Chilean regions, from Valparaíso in the north to Araucanía in the south. The events, which covered $80 \%$ of the country's population, killed more than 500 people and destroyed much of the area. Damage was estimated at about 12,000 injured, 800,000 displaced, and 400,000 houses, 4,000 schools, 79 hospitals, and 4,200 boats damaged. The epicenter was located between Curañipe and Cobquecura, 325 kilometers from the capital, Santiago. The earthquake had a magnitude of 8.8 on the Richter scale, the second strongest in the country's history and one of the five strongest ever recorded (The largest recorded earthquake was in Valdivia, Chile (U.S. Geological Survey, 2012)). The economic loss due to the earthquake was estimated at US\$30 billion for the Chilean economy and US\$7 billion for insurance companies. Tsunami warnings were issued in 
more than 50 countries, and the wave caused damage from the San Diego area of California to Japan, where damage to the fisheries business was estimated at US\$67 millions.

Evidence shows that natural disasters affect trading behavior (Hood et al., 2013), bank solvency (Klomp, 2014), and output variance (Raddatz, 2007). They have an ambiguous effect on economic growth (Loayza et al., 2012; Cavallo et al., 2013) and on the insurance industry (Wang and Kutan, 2013). They also have negative effects on human capital accumulation of the affected and subsequent generations (Miller and Caruso, 2015). In addition, countries with higher debt market development suffer smaller real consequences from disasters (Melecky and Raddatz, 2015). Governments can provide better conditions for successful strategies for managing catastrophic risks (Born and Klimaszewski-Blettner, 2013).

The exogeneity of earthquakes provides a natural experiment, which we approach using event studies. An extensive empirical literature presents evidence that stocks prices are highly and instantly reactive to shocks. We employ Chilean stock market data and control for increases in market volatility after the earthquake. This study contributes to the literature by investigating the impacts of a huge natural disaster on the behavior of the stock market of an emerging economy and by measuring any possible significant movement in volatility linked to this catastrophic event.

The remainder of the paper is organized as follows. Section 2 provides a literature review. Section 3 presents the data and methodology used in the analysis. Section 4 provides the empirical results. Finally, Section 5 concludes. 


\section{Literature Review}

Event studies are widely used to analyze the effects of natural disasters on stock returns. For example, Shelor et al. (1992) examine the 1989 California earthquake, Angbazo and Narayanan (1996) study the effect of hurricane Andrew on insurance companies in the United States, Worthington (2008) looks at natural disasters in Australia, and Takao et al. (2013) examine non-life insurance companies for the great east Japan earthquake. Shelor et al. analyze opposing hypotheses regarding to the impact of the California earthquake. They find that insurers' stock increases after the earthquake due to growing demand following the disaster rather than decreasing due to increased coverage payments. Angbazo and Narayanan find that insurance stocks decrease for hurricane Andrew (i.e., the increase in demand does not compensate the losses). Worthington finds no significant impact of natural disasters on Australian stock market using a GARCH specification. Takao et al. find that insurance companies' stock prices decrease immediately after the earthquake and the impact is less for non-life insurance companies than for life insurance companies. These studies are useful because the event's effect is immediately reflected in stock prices (Fama et al., 1969). Therefore, a measure of the economic impact of the event can be easily developed using the observed prices of securities over a short period of time.

\section{Data and methodology}

A. Data

We use daily close prices of stocks traded in Santiago Stock Exchange (BCS, in Spanish) adjusted by dividends obtained from the Economática database for the period from January 23, 2009 to April 6, 2010. We select 42 companies from a complete sample of 
131 companies by filtering out firms with less than 250 daily returns in the estimation period and those with missing values in the event window. Stocks that are traded infrequently are also removed because they can produce erroneous specifications in the statistical tests (Cowan and Sergeant, 1996). In addition, we use the Selective Price of Stock Index (IPSA, in Spanish) as a proxy of market, which corresponds to a profitability indicator of 40 shares with the highest market presence in the BCS.

The returns are computed in logarithms of the stock prices adjusted by dividends using the method applied by Fama (1965):

$$
R_{i, t}=\ln \left(P_{i, t}\right)-\ln \left(P_{i, t-1}\right),
$$

where

$R_{i, t}$ is the stock return of asset $i$ in $t$

$P_{i, t}$ is the price adjusted by dividends of the stock $i$ in $t$.

Table 1 provides the statistical summary of the daily returns of the sample. The firms have a positive skew in returns and excess of kurtosis. 
Table 1

Daily returns of forty two securities traded on the Santiago

Stock Exchange (BCS): Statistical summary.

\begin{tabular}{|c|c|c|c|c|c|}
\hline Firm & Economic Sector & Mean & Std. Dev. & Skewness & Kurtosis \\
\hline ALMENDRAL & Telecommunications & 0,0009 & 0,0140 & 0,0070 & 3,7350 \\
\hline ANDINA_B & Industrial (beberage) & 0,0008 & 0,0127 & $-0,0154$ & 4,2982 \\
\hline ANTARCHILE & Natural resources & 0,0017 & 0,0158 & 0,2935 & 4,3493 \\
\hline $\mathrm{BCI}$ & Services (bank) & 0,0017 & 0,0148 & 0,5006 & 4,2586 \\
\hline BSANTANDER & Services (bank) & 0,0019 & 0,0178 & $-0,1524$ & 3,2370 \\
\hline CALICHERAA & Natural resources & 0,0015 & 0,0148 & $-0,0046$ & 6,7411 \\
\hline CAP & Natural resources & 0,0029 & 0,0212 & 0,0801 & 3,6694 \\
\hline $\mathrm{CCU}$ & Industrial (beberage) & 0,0007 & 0,0152 & 0,1290 & 4,2097 \\
\hline CENCOSUD & Services (retail) & 0,0024 & 0,0169 & 0,2193 & 2,8739 \\
\hline CGE & Electric Power & 0,0006 & 0,0134 & 0,2536 & 4,9709 \\
\hline CHILE & Services (bank) & 0,0019 & 0,0133 & 0,3349 & 3,2060 \\
\hline COLBUN & Electric Power & 0,0010 & 0,0125 & 0,4255 & 3,6982 \\
\hline CONCHATORO & Industrial (beberage) & 0,0008 & 0,0155 & $-0,2396$ & 4,7515 \\
\hline COPEC & Natural resources (forestry) & 0,0018 & 0,0167 & 0,4107 & 3,9316 \\
\hline CORPBANCA & Services (bank) & 0,0025 & 0,0140 & 0,5668 & 5,0728 \\
\hline CUPRUM & Services (pension) & 0,0040 & 0,0171 & 2,6742 & 17,7416 \\
\hline EDELNOR & Natural resources & 0,0026 & 0,0167 & 1,1470 & 6,6197 \\
\hline ENDESA & Electric Power & 0,0007 & 0,0113 & 0,3109 & 3,8319 \\
\hline ENERSIS & Electric Power & 0,0011 & 0,0139 & 0,0343 & 3,6630 \\
\hline ENTEL & Telecommunications & 0,0006 & 0,0122 & 0,1127 & 3,6754 \\
\hline FALABELLA & Services (retail) & 0,0019 & 0,0156 & 0,1556 & 3,6999 \\
\hline GENER & Electric Power & 0,0010 & 0,0130 & 0,0505 & 3,8686 \\
\hline IAM & Natural resources (water) & 0,0012 & 0,0113 & 0,2280 & 6,8820 \\
\hline IANSA & Industrial (sugar) & 0,0043 & 0,0402 & 1,3527 & 15,0140 \\
\hline LA_POLAR & Services (retail) & 0,0038 & 0,0227 & 1,1994 & 9,8476 \\
\hline LAN & Services (Airline) & 0,0023 & 0,0152 & $-0,0647$ & 4,2911 \\
\hline MADECO & Industrial (wire and cable) & 0,0006 & 0,0167 & 0,5229 & 5,5877 \\
\hline MASISA & Industrial (wood) & 0,0014 & 0,0206 & 0,4184 & 4,4640 \\
\hline MULTIFOODS & Industrial (food) & 0,0026 & 0,0323 & 0,4068 & 10,4237 \\
\hline ORO_BLANCO & Natural resources & 0,0006 & 0,0165 & 0,1061 & 3,1109 \\
\hline PARĀUCO & Services (real estate) & 0,0026 & 0,0169 & 0,3053 & 3,9076 \\
\hline $\mathrm{PAZ}$ & Industrial (real estate) & 0,0034 & 0,0258 & 1,1041 & 7,9070 \\
\hline PILMAIQUEN & Industrial & $-0,0002$ & 0,0176 & 1,4944 & 9,4194 \\
\hline PROVIDA & Services (pension) & 0,0037 & 0,0135 & 0,3325 & 4,1763 \\
\hline RIPLEY & Services (retail) & 0,0015 & 0,0174 & 0,6250 & 4,6601 \\
\hline SALFACORP & Industrial & 0,0021 & 0,0195 & 0,9704 & 5,4577 \\
\hline SCHWAGER & Natural resources & 0,0023 & 0,0359 & 1,0394 & 11,8883 \\
\hline SM_CHILE_B & Natural resources & 0,0021 & 0,0138 & 1,6870 & 10,5122 \\
\hline SOCOVESA & Industrial (real estate) & 0,0027 & 0,0200 & 0,5581 & 4,7042 \\
\hline SONDA & Telecommunications & 0,0012 & 0,0104 & 0,4878 & 4,1427 \\
\hline SQM_B & Natural resources & 0,0008 & 0,0191 & $-0,5754$ & 4,0024 \\
\hline VAPORES & Services (transportation) & 0,0006 & 0,0243 & 1,1288 & 8,4712 \\
\hline
\end{tabular}

NotE: These data refer the estimations in the period from January 23, 2009 to April 6, 2010 (275 observations for each firm). The data source for economic sector is the Superintendence of Pension Funds, Chile. 


\section{B. Method}

The methodology of event studies is based on the hypothesis of efficient markets carried out by Fama et al. (1969). Investors take the new information as result of an unexpected event and value its impact on the present and future stock prices (McWilliams and Siegel, 1997; MacKinlay 1997). If the event conveys new information relevant to the stock market, the mean or variance of abnormal returns on securities must reflect the new economic conditions. Brown and Warner (1980, 1985) present empirical evidence that the distribution of daily returns exhibit substantial deviations from normality in terms of means and volatilities. We consider the notion of efficient markets in our analysis.

Boehmer et al. (1991) develop a methodology for event study based on volatility, which is later developed by Hilliard and Savickas (2002). The idea is to specify a market model for returns on securities in the $\operatorname{GARCH}(1,1)$ form to separate the systematic and unsystematic components of volatility. The model is given by

$$
\begin{aligned}
& R_{i, t}=\alpha_{i}+\beta_{i} R_{t}^{M}+\varepsilon_{i, t} \sim N\left(0, h_{i, t}\right) \\
& h_{i, t}=\gamma_{0}+\gamma_{1} h_{i, t-1}+\gamma_{2} \varepsilon_{i, t-1}^{2},
\end{aligned}
$$

where

$R_{i, t}$ and $R_{t}^{M}$ are the returns of stock $i$ and the market portfolio in period $t$, respectively

$\varepsilon_{i, t}$ is the error component, and

$h_{i, t}$ represents the conditional variance. They are estimated jointly using the maximum likelihood method for the period immediately preceding the event window period.

The abnormal conditional return for stock $i$ in period $t$ is given by 


$$
A R_{i, t}=R_{i, t}-E\left(R_{i, t} \mid \Omega_{t-1}\right)
$$

where

$A R_{i, t}, R_{i, t}$ y $E\left(R_{i, t} \mid \Omega_{\mathrm{t}-1}\right)$ are, respectively, the abnormal, current, and normal return expected for period $t$. Note that $\Omega_{t}$ is the set of conditional information in period $t$ and the approach followed by the event study methodology assumes the returns on securities are generated by a model generator returns.

Subsequently, the test to measure the statistical significance is

$$
\begin{aligned}
& \theta_{\tau}=\frac{A S R_{\tau}}{\sqrt{\sum_{i=1}^{N}\left(S R_{i, \tau}-A S R_{\tau}\right)^{2}}}(N-1) \\
& S R_{i, \tau}=\frac{A R_{i, \tau}}{\sqrt{\hat{h}_{i, t}}} \\
& A S R_{\tau}=\frac{\sum_{i=1}^{N} S R_{i, \tau}}{N} .
\end{aligned}
$$

To analyze the effect of the earthquake during any subperiod event window where temporal lower and upper days are defined as $m$ and $s$ (where $m<s$ ), the standardized cumulative abnormal return (SCAR) is calculated as

$$
S C A R_{i, m, s}=\frac{\sum_{t=m}^{s} A R_{i, \tau}}{\sqrt{\sum_{t=m}^{s} \hat{h}_{i, t}}} .
$$

Then the corresponding added statistical test is given by 


$$
\begin{aligned}
& \theta_{m, s}^{C A R}=A S C A R_{m, s} \sqrt{\frac{(N-1)}{\sum_{i=1}^{N}\left(S C A R_{i, m, s}-m, s\right)^{2}}} \\
& \operatorname{ASCAR}_{m, s}=\frac{\sum_{i=1}^{N} S C A R_{i, m, s}}{N} .
\end{aligned}
$$

As a next step, we study the event's effect on the volatility of stocks' returns using the method proposed by Hilliard and Savickas (2002). First, we consider the variation in $\varepsilon_{i, t}$ around the event date in relation to its regular level when the event does not occur. The GARCH model can be useful as benchmark as it provides an indication of the potential volatility level if the event had not occurred (Bialkowski et al., 2006). However, we must ensure that this projection is independent of the event; otherwise, the immediate impact of the earthquake, measured by $\varepsilon_{i, 0}$ will have a weight on values $h_{i, t}$ for any $t>0$. This problem can be dealt with simply by making the volatility forecast conditional only on the set of information available prior to the event. Therefore, the benchmark volatility for the $k$ th day of the event window is defined as a forecast of $k$-steps-ahead of the conditional variance based on the set of information available on the last day of the estimation window $T_{1}$ :

$$
\begin{aligned}
E\left[h_{i, T_{1+k}} \mid \Omega_{T_{1}}\right] & =\hat{\gamma}_{0} \sum_{j=0}^{k-1}\left(\hat{\gamma}_{1}+\hat{\gamma}_{2}\right)^{j}+\left(\hat{\gamma}_{1}+\hat{\gamma}_{2}\right)^{k-1} \hat{\gamma}_{1} h_{i, T_{1}}+ \\
& +\left(\hat{\gamma}_{1} \hat{\gamma}_{2}\right)^{k-1} \hat{\gamma}_{2} \hat{\varepsilon}_{i, T_{1}}^{2} .
\end{aligned}
$$

Thus, the residual distribution during the event window is described as $\varepsilon_{i, t} \sim N\left(A R_{t}, M_{t} \cdot E\left[h_{i, t} \mid \Omega_{T_{1}}\right]\right)$, where $M_{t}$ is the multiplicative effect of the event above the volatility. For example, if $M_{t}=1$, the event does not affect stock volatility if $M_{t}<1$ implies that the event causes a decrease in volatility. Therefore, the event is characterized by a set of $M_{t}$, having a value of $M$ for each day of the event window. Then 


$$
\hat{M}_{t}=\frac{1}{N-1} \sum_{i=1}^{N} \frac{\left(N \cdot \hat{\varepsilon}_{i, t}-\sum_{j=1}^{N} \hat{\varepsilon}_{j, t}\right)^{2}}{N \cdot(N-2) \cdot E\left[h_{i, t} \mid \Omega_{T_{1}}\right]+\sum_{j=1}^{N} E\left[h_{j, t} \mid \Omega_{T_{1}}\right]},
$$

where

$\hat{\varepsilon}_{i, t}=R_{i, \tau}-\left(\hat{\alpha}_{i}-\hat{\beta}_{i} R_{t}^{M}\right)$ and $t>T_{1}$.

Considering the null hypothesis $M_{t}$ is 1 , the percentage change in volatility for any day $t$ if the event window is $\left(\hat{M}_{t}-1\right)$ Also, for a window event $\left(n_{1}, n_{2}\right)$, the cumulative abnormal volatility (CAV) is

$$
\operatorname{CAV}\left(n_{1}, n_{2}\right)=\left(\sum_{t=n_{1}}^{n_{2}} \hat{M}_{t}\right)-\left(n_{2}-n_{1}+1\right)
$$

The null hypothesis of no impact is expressed as

$$
H_{0}: C A V\left(n_{1}, n_{2}\right)=0 \text {. }
$$

Then

$$
H_{0}: \sum_{t=n_{1}}^{n_{2}} M_{t}(N-1)=\left(n_{2}-n_{1}+1\right) \cdot(N-1)
$$

Under the null hypothesis, $M_{t}$ is a variance of $N$ independent random variables, and it is distributed as $N(0,1), \hat{M}_{t}(N-1) \sim X_{(N-1)}^{2}$ and $\sum_{t=n_{1}}^{n_{2}} M_{t}(N-1) \sim X_{(N-1)\left(n_{2}-n_{1}+1\right)}^{2}$.

Therefore, the statistic test for the hypothesis is

$$
\phi\left(n_{1}, n_{2}\right)=\sum_{t=n_{1}}^{n_{2}}(N-1) \cdot \hat{M}_{t} \sim X_{(N-1)\left(n_{2}-n_{1}+1\right)}^{2} .
$$




\section{Empirical Results}

We define the day of the event as the first day that Santiago Stock Exchange conducted its operations after the earthquake and tsunami (March 1, 2010). Tables 2 and 3 provide the standardized abnormal returns and corresponding descriptive statistics, respectively.

Banks have a positive abnormal return in general. BCI has positive abnormal returns for the days $t=+1,+2$. Chile has also positive abnormal returns for the day $t=+1$, and Santander also has positive abnormal returns for the day $t=+1,+7$. These banks are oriented to middle and upper economic salaries, and we can expect a credit expansion to these groups.

Soquimich (SQM-B), which produces and distributes iodine, lithium, and fertilizers, experiences positive abnormal returns for day $t=+1$. This company announced that the earthquake did not cause significant damage to its production facilities but did affect its inventory, which was covered by insurance. Thus the company did not expect a significant adverse effect on its returns.

La Polar, a retail firm, has abnormal negative returns for the day $t=+3$. The enterprise suffered damaged in Concepción, the second biggest Chilean city, and a reduction in consumption levels of its targeted socioeconomic group. The returns are positive the first days for other retail firms (Falabella, Cencosud, and Ripley), but they turn negative for the day $t=+3$ or $t=+4$. We expect an increase in the net demand for clothing and utensils. The salmon firm Multifoods experiences a significant negative abnormal return on the day $t=0$. The negative returns during the first day following the earthquake can be attributed to the looting that occurred in the ports and boarding areas at the time of the disaster. 


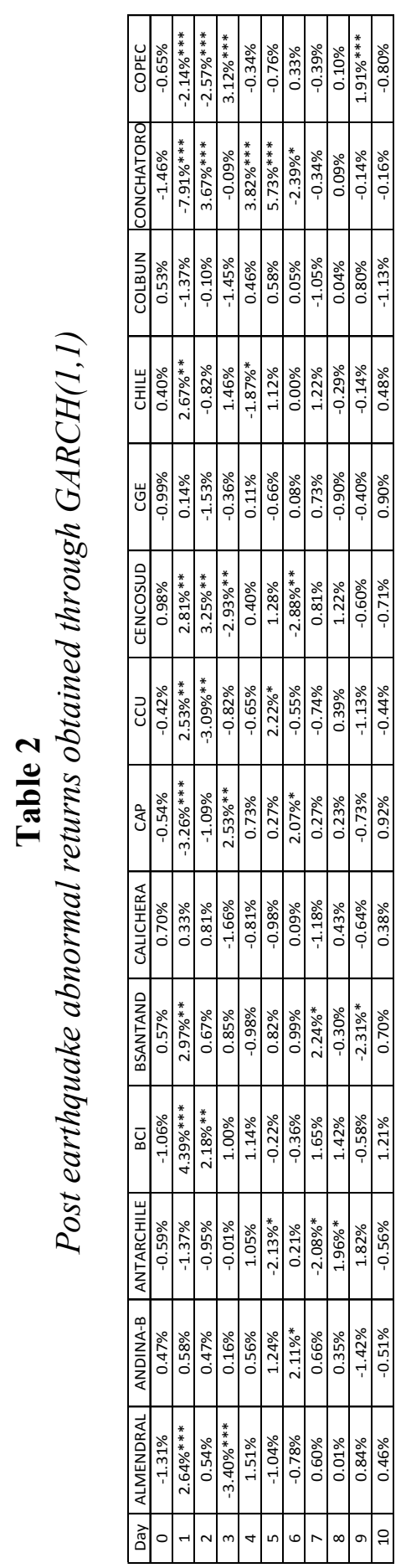

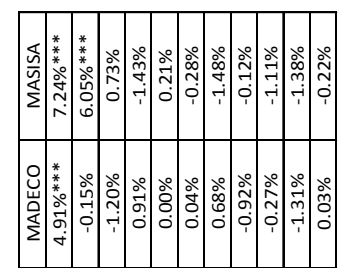
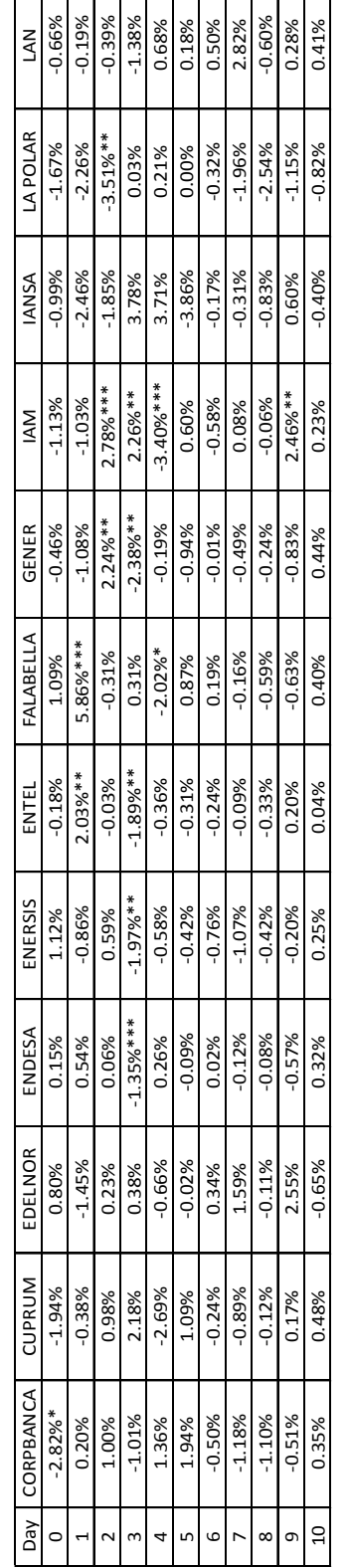
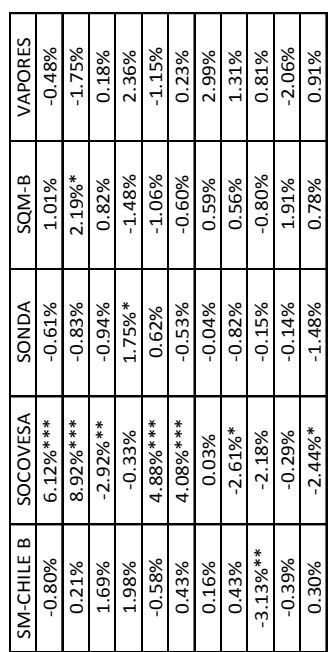

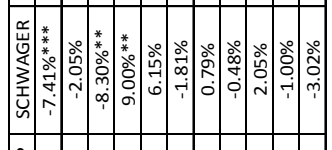

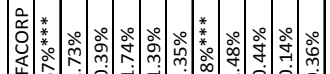

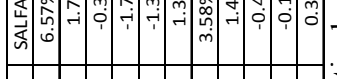

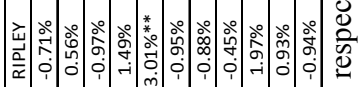

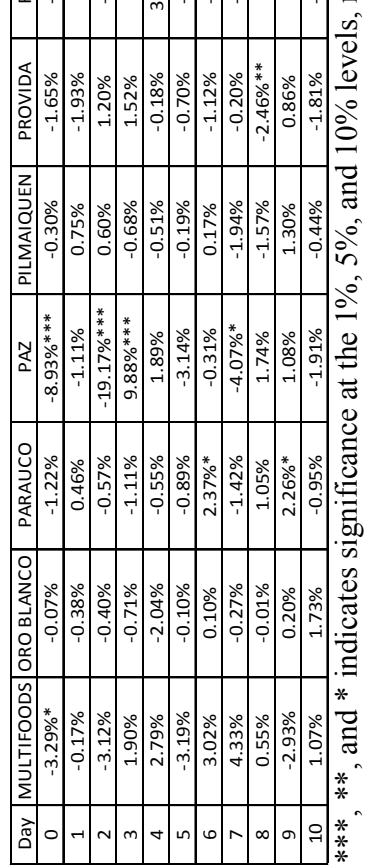


Table 3

Descriptive statistics and abnormal returns $t$-test through $\operatorname{GARCH}(1,1)$

\begin{tabular}{c|c|c|c|c|c|c|c}
\hline \multicolumn{7}{c}{ DESCRIPTIVE STATISTICS } \\
\hline DAY & MIN \% & AVERAGE $\%$ & MAX \% & StD DEV \% & SKEWNESS & KuRTOSIS & T-TEST \\
\hline 0 & -8.93 & -0.23 & 7.24 & 2.87 & 0.0450 & 5.94 & -0.01 \\
\hline+1 & -7.91 & 0.34 & 8.92 & 2.82 & 0.4444 & 5.08 & 1.12 \\
\hline+2 & -19.17 & -0.70 & 3.67 & 3.58 & -3.4956 & 18.31 & -0.95 \\
\hline+3 & -3.40 & 0.49 & 9.88 & 2.65 & 1.7426 & 7.04 & 0.28 \\
\hline+4 & -3.40 & 0.32 & 6.15 & 1.94 & 0.9550 & 4.18 & 0.57 \\
\hline+5 & -3.86 & 0.01 & 5.73 & 1.70 & 0.7096 & 5.61 & 0.50 \\
\hline+6 & -2.88 & 0.19 & 3.58 & 1.28 & 0.5990 & 4.19 & 0.49 \\
\hline+7 & -4.07 & -0.11 & 4.33 & 1.49 & 0.3112 & 4.36 & -0.85 \\
\hline+8 & -3.13 & -0.15 & 2.05 & 1.17 & -0.3217 & 3.41 & -1.07 \\
\hline+9 & -2.93 & -0.03 & 2.55 & 1.27 & 0.1914 & 2.79 & 0.20 \\
\hline+10 & -3.02 & -0.15 & 1.73 & 1.00 & -0.8250 & 3.59 & -0.70 \\
\hline SOURE:
\end{tabular}

SOURCE: Authors' calculations based on Santiago Stock Exchange (BCS) adjusted by dividends obtained from Economática database.

The real estate company Paz reports significant negative abnormal returns for $t=0,+2,+3,+7$. These negative returns are attributed to structural damage reported for two of its buildings, hurting its reputation. Conversely, Salfacorp, a construction firm, shows significant positive abnormal returns for days $t=0,+6$. These returns can be attributed to an expected increased construction in the short and medium term from repairing structural damage.

From the estimator presented in equation (12), we obtain the multiplicative abnormal volatility for each day within the event window $(-15,+15)$. The earthquake event is accompanied by a significant increase in volatility. An abnormal increase appears from day $t=0$ and continues for several days. The market is back to normal day by day $t=5$, when the multiplier effect again approaches $M_{t}=1$. This reaction of several days is possibly caused 
by uncertainty due to a lack of data in that period; that is, the market players were waiting for new information about the state of the facilities and operations of each firm after the earthquake, the impact it had on the local economy, and the possible adjustment that may occur in consumption and investment decisions of market participants.

Table 4 presents the cumulated abnormal volatility (CAV) calculated using equation (13). Panels $\mathrm{A}$ and $\mathrm{B}$ provide the results obtained using an asymmetrical and symmetrical windows event, respectively, centered on the day of the earthquake. $\operatorname{CAV}(-10,+10)$ is valued at 6.14. The CAV ratio of the total number of days included in the window of the event is, by construction, equivalent to the percentage increase in volatility relative to its benchmark. Within the 21-day window surrounding the earthquake, the variance was $56 \%$ higher than it would have been if the earthquake had not occurred. Narrowing the event window leads to higher implicit percentage changes, confirming that most of the large stock movements in the capital market are concentrated around the day of the earthquake. Volatility doubles during the week when the earthquake struck. The results show that the null hypothesis of no impact is rejected at a significance level of $1 \%$.

\section{Table 4}

Cumulative abnormal volatility around the earthquake

\begin{tabular}{l|c|c}
\hline WindOw & $\operatorname{CAv}(n 1, n 2)$ & IMPLicit CHANGE (\%) \\
\hline Panel A: Asymmetric window & & \\
\hline$(0,+5)$ & 14.43 & 240 \\
\hline$(0,+10)$ & 13.18 & 120 \\
\hline Panel B: Symmetric window & & 184 \\
\hline$(-5,+5)$ & 20.19 & 56 \\
\hline$(+10,+10)$ & 6.14 & 7 \\
\hline$(+15,+15)$ & 2.28 & \\
\hline
\end{tabular}

SOURCE: Authors' own based on Santiago Stock Exchange (BCS) adjusted by dividends obtained from Economática database. 


\section{Conclusions}

This study explores the price reaction and stock market volatility in Chile as a consequence of the earthquake in 2010. The analysis uses an event-study framework to contribute to a growing literature that estimates the impact of natural disasters. The results are informative about the behavior of stock prices in specific industry sectors. Namely, we find significant positive returns retail (increased purchase of technology and clothing products), construction (greater demand of cement, wood, wire, and cables), and banking (increased credit demands) and significant and negative returns in real estate (for firms that suffered issues on buildings), food (destroy of facilities), steel (destroy of facilities), and forestry (destroy of routes). In general, the impact on stocks is less reactive given the presence of mandatory insurance coverage on companies that belong to the IPSA stock index and the large earthquake tradition in Chile. Chilean stock market volatility increased by $240 \%$ (120\%) during the 5 (11) trading days after the earthquake. This huge increase in volatility generates investment opportunities for traders and reinforces the role of policymakers to extend insurance coverage for companies. 


\section{References}

ANGBAZO, L. A. and R. NARAYANAN (1996), "Catastrophic shocks in the property liability insurance industry: Evidence on regulatory and contagion effects", Journal of Risk and Insurance, Vol. 63(4), pp. 619-637.

BiAlKOWSKI, J. P., K. GOTTSCHALK and T.P WiSNIEWSKI (2006), "Stock market volatility around national elections", Journal of Banking and Finance, Vol. 32, pp. 941-1953.

Boehmer, E., J. MAsumeCI and A.B. Poulsen (1991), "Event-study methodology under conditions of event-induced variance", Journal of Financial Economics, Vol. 30(2), pp. 253-272.

Born, P. and B. KLIMASZEWSKI-BLETTNER (2013), "Should I stay or should I go? The impact of natural disasters and regulation on U.S. property insurers' supply decisions", Journal of Risk and Insurance, Vol. 80 (1), pp. 1-36.

BROWN, S. J., \& WARNER, J. B., 1980. "Measuring security price performance", Journal of Financial Economics, 8(3), 205-258.

BROWN, S. J., \& WARNER, J. B., 1985. "Using daily stock returns: The case of event studies", Journal of Financial Economics, 14(1), 3-31.

Cavallo, E., Galiani, S. Noy, I., \& Pantano, J. 2013. "Catastrophic natural disasters and economic growth", Review of Econonics and Statistics, 95(5), 1549-1561.

Cowan, A. R. and A.M. Sergeant (1996), "Trading frequency and event study test specification”, Journal of Banking and Finance, Vol. 20, pp. 17311757.

FAMA, E. F. 1(965), “The behavior of stock-market prices”, Journal of Business, Vol. 38(1), pp. 34105.

FAMA, E. F., L. FisheR, M.C. JENSEN and R. Roll (1969), "The adjustment of stock prices to new information", International Economic Review, Vol. 10(1), pp. 1-21.

HILLIARD, J. E. and R SAVICKAS (2002), "On the statistical significance of event effects on unsystematic volatility", Journal of Financial Research, Vol. 25(4), pp. 447-462. 
Hood, M., A. KamesakA, J. Nofsinger and T. TAMURA (2013), "Investor response to a natural disaster: Evidence from Japan's 2011 earthquake", Pacific-Basin Finance Journal, Vol. 25, pp. 240-252.

KlOMP, J. (2014), "Financial fragility and natural disasters: An empirical analysis", Journal of Financial Stability, Vol. 13, pp. 180-192.

LoAyza, N., E. OlaberríA, J. Rigolini and L. Christiaensen (2012), "Natural disasters and growth: Going beyond the averages", World Development, Vol. 40(7), pp. 13171336.

MACKInLAY, A.C. (1997), "Event studies in economics and finance", Journal of Economic Literature, Vol. 35(1), pp. 13-39.

MCWilliams, A. and D. Siegel (1997), "Event studies in management research: Theoretical and empirical issues", Academy of Management Journal, Vol. 40(3), pp. 626-657.

MELECKY, M. and C. RADDATZ (2015), "Fiscal responses after catastrophes and the enabling role of financial development", World Bank Economic Review, Vol. 29(1), pp. 129-149.

Miller, S. and G. CARUSO (2015), "Long run effects and intergenerational transmission of natural disasters: A case study on the 1970 Ancash Earthquake", Journal of Development Economics, Vol. 117, pp. 134-150.

RADDATZ, C. (2007), “Are external shocks responsible for the instability of output in low-income countries?" Journal of Development Economics, Vol. 84(1), pp. 155187

Shelor, R. M., D.C. Anderson and M.L. Cross (1992), "Gaining from loss: Property-liability insurer stock values in the aftermath of the 1989 California earthquake", Journal of Risk and Insurance, Vol. 59(3), pp. 476488.

TaKaO, A., T. Yoshizawa, S. Hsu and T. YamasaKi (2013), "The effect of the Great East Japan earthquake on the stock prices of non-life insurance companies", Geneva Papers on Risk and Insurance, Vol. 38, pp. 449468.

U.S. GeOlOGiCAL SURVEY (2012), "Largest earthquakes in the world since 1900". Available at: http://earthquake.usgs.gov/earthquakes/world/10_largest world .php. Accessed: June 30, 2015. 
WANG, L. and A.M. KUTAN (2013), "The impact of natural disasters on stock markets: Evidence from Japan and the US", Comparative Economic Studies, Vol. 55, pp. 672-686.

Worthington, A. C. (2008), “The impact of natural events and disasters on the Australian stock market: a GARCH-M analysis of storms, floods, cyclones, earthquakes and bushfires", Global Business and Economics Review, Vol, 10(1), pp. 1-10. 